\title{
THE IMPLEMENTATION OF BLENDED LEARNING APPROACH IN HIGHER EDUCATION INSTITUTIONS - A SOLUTION TO TEACHING ENGLISH IN LARGE CLASSES
}

\author{
Hoang Thi Thu Hoai ${ }^{1}$, Tran Thi Thao ${ }^{2 *}$ \\ ${ }^{I}$ Thai Nguyen Medical College, ${ }^{2}$ TNU University of Education
}

\section{ABSTRACT}

Teaching English in large classes has presented teachers many challenges, especially in higher education institutions. It is difficult for teacher to discipline the class, especially for students who are lack of self-control. The oversize classes also causes problems in carrying out teaching practices as well as assessment activities. It is problematic in satisfying all the needs of students who have different interests, personalities and capabilities. This paper attempts to suggest a learning approach that is believed to solve the problem; the blended learning. This is not a new idea in language teaching literature. However, the combination between traditional face-to-face classroom and the application of Internet and communication technology might lessen the burden for the teachers because of the advantages of the learning approach. Students can develop selfregulated learning styles meanwhile teachers can take control of what their learners do outside classroom. We strongly believe that the blended learning approach once carefully studied will be the trend for future education.

Key words: large classes; challenges; blended learning; self-control; self-regulated

Received: 02/5/2019; Revised: 31/5/2019; Approved: $31 / 5 / 2019$

\section{ÚNG DỤNG ĐƯờNG HƯớNG DẠY HỌC KẾT HợP TRONG GIÁO DỤC ĐẠI HỌC - MỘT GIẢI PHÁP CHO NHỬNG LỚP HỌC ĐÔNG SINH VIÊN

\author{
Hoàng Thị Thu Hoài ${ }^{1}$, Trần Thị Thảo ${ }^{2^{*}}$ \\ ${ }^{1}$ Trưòng Cao đẳng Y tế Thái Nguyên \\ ${ }^{2}$ Truờng Đại họ Su phạm - ĐH Thái Nguyên
}

\section{TÓM TẮT}

Việc giảng dạy tiếng Anh cho những lớp học đông sinh viên đã gây ra nhiều thách thức cho giáo viên, đặc biệt trong giáo dục đại học. Giáo viên khó triển khai các hoạt động duy trì kỷ luật lớp học, nhất là đối với những sinh viên thiếu ý thức làm chủ bản thân. Việc dạy học trong những lớp học đông sinh viên cũng gây nhiều khó khăn cho công tác giảng dạy, cũng như các hoạt động kiểm tra, đánh giá. Hơn nữa giáo viên khó lòng đáp ứng hết nhu cầu khác nhau của sinh viên. Bài viết này hướng tới việc giới thiệu một phương pháp dạy, học được tin là sẽ giải quyết được phần nào vấn đề lớp học đông sinh viên, phương pháp dạy, học kết hợp. Đây không phải là một ý tưởng mới. Tuy nhiên, việc kết hợp giữa mô hình lớp học truyền thống và ứng dụng công nghệ thông tin trong giảng dạy và học tập sẽ giúp phần giảm áp lực cho giáo viên. Sinh viên sẽ phát triển được phương pháp học tự chủ trong khi giáo viên vẫn kiểm soát được các hoạt động bên ngoài lớp học của sinh viên. Chúng tôi tin tưởng rằng phương pháp dạy, học kết hợp này nểu được nghiên cứu một cách toàn diện sẽ trở thành xu hướng giáo dục của tương lại.

Từ khóa: Lớp học đông sinh viên; thách thức; dạy; học kết hợp; tụ chủ; tụ kỷ luật

Ngày nhận bài: 02/5/2019; Ngày hoàn thiện: 31/5/2019; Ngày duyệt đăng: 31 /5/2019

* Corresponding author. Email: thaott.dhsptn@gmail.com

DOI: https://doi.org/10.34238/tnu-jst.2019.06.978 


\section{Introduction}

\subsection{Rationales}

It is a fact that many universities are facing growing enrollments that push the limits on the scalability of classroom pedagogies. For example, providing students the opportunity to orally present technical work becomes challenging as the number of students per class grows to large numbers. Additionally, the personalization of knowledge is also affected because of the numbers of students in a class.

Teachers of English at institutions of Thai Nguyen University are not an exception. They are struggling with teaching overcrowded classes which affect them in teaching performance, classroom management and assessment activities. The ineffectiveness of teaching large classes has been reported in many researches not only in Vietnam but also in many countries where English is taught as a second language or a foreign language [1], [2], [3].

This paper attempts to present a teaching approach that can lessen the burdens for those teachers at higher education institutions (HEIs) at Thai Nguyen University, the blended teaching and learning approach.

\subsection{Tendencies of blended learning}

Bended learning refers to combining traditional face-to-face learning environments with online education tools and approaches. With the ubiquitous use of laptops by students and the proliferation of low and no cost tools to facilitate online education, opportunities for blended learning are more available now than ever before.

Over the last few years, HEIs have seen significant changes with the participation of the Internet and ubiquitous technologies in individuals' lives [4]. It is undoubtedly that the Internet has considerably influenced the ways in which individuals across the world communicate, share ideas, interact with each other, and express themselves. Along with this remarkable spread, information and communication technologies (ICTs) have played an important role not only in designing, developing and delivering educational courses but also in enhancing and enriching the quality of teaching and learning experiences [5]. Therefore, numerous educational institutions, mostly in developed and industrialized countries, have adopted the use of ICTs so as to enhance the quality of teaching and learning processes.

In 2002, the editor of The Journal of Asynchronous Learning Networks predicted that approximately $80-90 \%$ of higher education courses would become blended in the future [6]. In 2004, scholars reported that $45.9 \%$ of U.S. undergraduate institutions already offered blended courses [7]. In 2011, scholars noted the "explosive growth of blended learning" and acknowledged blended learning's potential to become the "new normal" in higher education [8].

\section{A review of related literature}

\subsection{Corollaries of large class size in ELT context}

The English language teaching (ELT) context at institutions of Thai Nguyen University, especially non-majored English students at the College of Education confronts many challenges for teachers of English. One of the challenges is the overcrowded classes. It is a fact that in many classes the number of students may reach to 50,60 or more. The teaching performance as well as classroom management becomes less effective. We all know that the more the number of students is, the more difficulties of the classroom management are. Teaching effect is just like magnetic or electric field, the larger classroom, the weaker teaching effect. The less classroom controls, the more serious phenomenon of the students "fake participation" [9]. Since the new features and 
the contradiction of the large classroom have appeared, disorder, hard to control, lack of language training, etc. could always occur. Even if the implementation of the communicative approach and task-based teaching, teachers will also feel anxious, inadequate, inefficient, and ineffective, unless adopt effective management.

LoCastro [10, p.113] generated the list of problems related to class size and language learning, organized into three categories:

- Pedagogical-related categories

- more difficulties in carrying out speaking, reading, and writing tasks;

- difficulties in monitoring work and giving feedback;

- problems with individualizing work;

- difficulties in setting up communicative tasks;

- tendency to avoid activities that are demanding to implement.

- Management-related categories

- correction of large numbers of essays virtually impossible;

- pair and group work often cumbersome to execute;

- noise level high, affecting neighboring classes;

- difficulties in attending to all students during class time;

- discipline problems more acute.

- Affective related categories

- difficulties in learning students' names;

- impossibility of establishing good rapport with students;

- concerns for weaker students who may get lost;

- crowd phenomenon: students' not listening to teacher and other students;

- problems in assessing students' interests and moods.

Hayes (1997) [11] classifies the problems associated with teaching in large classes into five categories: (1) Discomfort caused by the physical constraints; (2) Control problems (discipline aspects); (3) Lack of individual attentions; (4) Difficulty on evaluation; (5) Problems of charging learning effectiveness. These problems can be physical, psychological but to a great extent technical. Harmer (2000) [12] also finds out in his study that large classes bring difficulties to both teachers and students and process of teaching and learning. It is difficult for teachers to contact with the students sitting at the back and for students to get the individual attention, and it is even impossible to organize dynamic and creative teaching and learning sessions. Most importantly, large classes are especially daunting for inexperienced teachers. This also indicates that teachers need more technical strategies in large class.

In large classroom teaching process, students' dependence on teachers cannot be reduced, until they are taught how to learn. Only when the students get some self-learning ability under the guidance of teachers, can they learn by themselves and improve the ability of obtaining knowledge. It seems to be difficult to reduce the class size in these classes because they are non-English majored students, i.e., these students learn English as a subject in their program. Besides, there are not enough time and teachers to split up these groups. Therefore, it is important to adopt advantages of Internet and communication technologies (ICTs) in the teaching and learning practices, so blended learning might be the solution for the problem.

\subsection{How is blended learning defined?}

The term "blended learning", sometimes is referred to as "hybrid learning" is a mixing of online activities with face-to-face classes. Generally speaking, some consider blended learning to be when some amount of the normally allotted face-to-face time for a 
course is substituted by online activities [13]. The former Sloan Consortium, now the Online Learning Consortium, stated that a course can be considered blended when the amount of online time replaces from $30 \%$ to $79 \%$ of the total course time [7]. Others are not concerned whether or not in-class time is replaced but choose to focus on different aspects of the blend. For example, Garrison and Vaughan [14, p. 148] view blended learning as "the organic integration of thoughtfully selected and complementary face-to-face and online approaches and technologies". Looking at learning from cognitive perspectives, Singh (2003) [15] perceived blended learning as a significant and motivating learning approach that incorporated diverse delivery media. In a recent study by Sabri, Isa, Daud, and Aziz (2010) [16], they defined blended learning as an integration of conventional classroom teaching with a combination of media, tools and teaching methods in web-based environment settings. As mentioned by Zhang (2010) [17], blended learning is not a replacement of the face-to-face class education with a web-based education. On the other hand, blended learning is a superior single delivery teaching approach that combines advantages of both conventional face-to-face classroom instructions with an online learning experience. The term has evolved to include so much more. The Innosight Institute [18, p.4] defines blended learning as:

A formal education program in which a student learns at least in part through online delivery of content and instruction with some element of student control-over time, place, path, and/or pace and at least in part at a supervised brick-and mortar location away from home.

The phrase "with some element of student control over time, place, path, and/or pace" was added to distinguish blended learning from technology-rich instruction [18, p.6]. Ten years prior, Stahl (2002) [19] clearly outlined the four dimensions of time, place, path, and pace. Time means that learning is no longer limited to a traditional school day or school calendar year. Place refers to learning that is no longer limited to the traditional classroom. Path can be defined as learning that is no longer limited to the faceto-face strategies used by the teacher. Pace is described as learning that is no longer limited to the pace of the entire class, but is individualized. The second part of the definition states that the learning must be "supervised" and take place off campus. This is to make the distinction between students learning full-time online at a brick-and-mortar location and off campus such at the student's home or self-chosen location.

For whatever blended learning is defined, it is undoubtedly understood that the combination of traditional teaching and learning methods and the implementation of ICTs is the inevitable trend of future schooling. The pure face-to-face practice is no longer satisfied the increasing demands of modern learning and teaching.

\subsection{What are the benefits of blended learning?}

According to Singh (2004), blended learning is expanded to five dimensions. The first is the simplest level - a blended learning experience that combines offline and online forms of learning where the online learning usually means "over the internet or intranet" and offline learning that happens in a more traditional classroom setting [20]. Second is the blending of a self-paced and live, collaborative learning. Self-paced learning implies solitary, on-demand learning at a pace that is managed or controlled by the learner. Collaborative learning, on the other hand, implies a more dynamic communication among many learners that brings about 
knowledge sharing [20]. Third is the combination of structured and unstructured learning. Formal learning program is in organized content with specific sequence like chapters in a textbook. On the other hand, most learning in the workplace occurs in an unstructured form via meetings, hallway conversations, or email [20]. The fourth dimension is blending custom content with off-the shelf content. Off-the-shelf content is by definition generic- unaware of an organization's unique context and requirements. However, generic self-paced content can be customized today with a blend of live experiences or with content customization [20]. Fifth level is blending learning, practice, and performance support. Perhaps the finest form of blended learning is to supplement learning with practice and justin-time performance support tools that facilitate the appropriate execution of jobtasks [20].

Ekesionye \& Okolo (2011) [21] maintain that, blended learning application ensures that teaching and learning are information and communication technology based, and it has the following benefits:

- Enable students to have equal opportunities with their contemporaries in other part of the world.

- Could be used to introduce an interesting variety of the inventory of instructional materials.

- Exposes students and teachers to basic skills in Computer Education for the purpose of accessing the internet and sourcing of information for effective learning.

- Helps teachers and students to be comfortably entrenched in the global village.

- Exposes the teachers and learners to instructional best practices in information technology.
- Facilitate teaching, knowledge creation and dissemination of information in the tertiary institution.

From the above-mentioned benefits of blended learning, we strongly believe that this approach will partly lessen the burdens for teachers who are teaching English in large classes. During the offline sessions, students are presented with something related to theories or knowledge of language. Then they will do the practice and drills following the online sessions. However, we all know that each solution has its drawbacks, blended learning is not an exception. We need technical preparedness for the issues such as computer, internet access and knowledge of ICT, but the advantages outweigh the limitations.

\section{Conclusions}

In conclusion, blended learning approach once considered carefully will be a perfect solution for the overcrowded classes. Besides, the approach can help students develop selfcontrolled and self -regulated learning. The teachers can track down what students do outside classroom. The approach can also applicable for many other subjects rather than English teaching and learning with the assistance of modern technologies.

\section{REFERENCES}

[1]. Gibbs, G. \& Jenkins, A. (Eds.), Teaching large classes in higher educatin, London: Kogan, 1992.

[2]. Hess, N., Teaching large multievel classes, Cambridge: CUP, 2001.

[3]. Hoxby, C.M., "The effects of class size on student achievement: New evidence from populatin variation", Quarterly Journal of Economics, 115, pp. 1239-1285, 2000.

[4]. Bates, T., "Understanding Web 2.0 and it's implications for e-learning", In W. Lee \& C. McLoughlin, eds. Web 2.0-based e-learning: Applying social informatics for tertiary teaching, New York: Information Science Reference, 2011. 
[5]. Oliver, R., The Role of ICT in higher education for the 21st century: ICT as a change agent for education, 2002. Available at: http://bhs-ict.pbworks.com/f/role of ict.pdf.

[6]. Young, J. R., "Hybrid" Teaching Seeks to End the Divide Between Traditional and Online Instruction, Chronicle of Higher Education, 48(28), 2002.

[7]. Allen, I. E., Seaman, J., \& Garrett, R., Blending in: The extent and promise of blended education in the United States, Proceedings of The Sloan Consortium, 2007, Retrieved from http://sloanconsortium.org/ sites/default/ files/Blending_In.pdf

[8]. Norberg, A., Dziuban, C. D., \& Moskal, P. D., A time-based blended learning model. On the Horizon, 19(3), pp. 207-216, 2011. doi:10.1108/10748121111163913

[9]. Weixuan, Z., A Brief Analysis of Large Classroom's English Teaching Management Skills. Beijing, 2014

[10]. LoCastro, V., Large size classes: The situation in Japan (Project Report No. 5). Leeds, England: Lancaster-Leeds Language Learning in Large Classes Research Project, 1989.

[11]. Hayes, U., Helping teachers to cope with large classes. ELT Journal, S 1, 31-38, 1997.

[12]. Harmer, J., How to Teach English, Foreign Language Teaching and Research Press, 2000.

[13]. Parsad, B., Lewis, L., \& Tice, P., Distance education at degree-granting postsecondary institutions: 2006 - 07. Washington, D.C.: National Center for Education Statistics, Institute of Education Sciences, U.S. Department of Education, 2008. Retrieved March 19, 2017 from http://nces.ed.gov/ pubs2009/2009044.pdf

[14]. Garrison, D. R., \& Vaughan, N. D., Blended learning in higher education: Framework, principles, and guidelines. San Francisco, CA: Jossey-Bass, 2008.
[15]. Singh, H., "Building effective blended learning programs", Journal of Educational Technology, 43, pp. 51-54, 2003.

[16]. Sabri, N. M., Isa, N., Daud, N. M. N., Aziz, A. A., Lecturers' Experiences in Implementing Blended Learning Using iLearn. Proceeding ofInternational Conference on Science and Social Research (pp. 580585). Kuala Lumpur, Malaysia: Universiti Teknologi MARA, 2010.

[17]. Zhang, Y., "Application of Blended Learning Model Based on PCR", Proceeding of International Conference on E-Health Networking, Digital Ecosystems and Technologies (pp. 400-401). Shenzhen, China : Shenzheng University, 2010.

[18]. Staker, H., \& Horn, M. B., Classifying K-12 blended learning, 2012. Retrieved from http://files.eric.ed.gov/fulltext/ED535180.pdf

[19]. Stahl, G., Contributions to a theoretical framework for CSCL, Paper presented at the Computer support for collaborative learning: Foundations for a CSCL community. In proceedings of the conference on computer support for collaborative learning: Foundations for a CSCL community (pp. 6271). International Society of the Learning Sciences, 2002, Retrieved from http://GerryStahl.net/cscl/papers/ch15.pdf

[20]. Singh H., "Building Effective Blended Learning Programs", November 2003 Issue of Educational Technology, Volume 43. USA, 2004.

[21]. Ekesionye, N. E. \& Okolo A. N., "Optimizing E-learning Opportunities: A Effective and Necessary Tool Towards Branding Higher Education in Nigerian Society", In Onyegegbu, N. and Eze, U. (eds), Optimizing E-learning Opportunities for Effective Education Service Delivery. Publication of Institute of Education (UNN), (2011). 